\title{
Statistical Evaluation of The Heavy Metals in the Sediments of Warri River and Environs
}

\author{
P. N. Jire ${ }^{1}$, E.G. Imeokparia ${ }^{2}$ \\ ${ }^{1,2}$ Department of Geology, University of Benin, Benin City, Nigeria \\ g_imeokparia@yahoo.com
}

\begin{abstract}
This study was carried out to assess and characterize the pollution/contamination status of the sediments in Warri River and its environs in view of the increasing level of oil spillages induced by willful acts of vandalization, lack of maintenance of pipelines, aging facilities, accident, illegal bunkering, petroleum refinery and production, urbanization, industrial activities and indiscriminate dumping of wastes.
\end{abstract}

A total of thirty-two sediments samples were collected from eight sampling stations, grouped into locations B1-B8 respectively and analyzed for heavy metals. The chemical data set generated were subjected to principal component analysis (PCA)/factor analysis (FA) and Hierarchical cluster analysis (HCA) to determine the subtle factors responsible for their distribution. The heavy metal concentrations of locations B1-B8 were further evaluated using enrichment factor (EF), Contamination factor (CF) and Pollution load index (PLI) to assess the level of pollution in the area.

The Factor Analysis results revealed four sources of pollutants which are explained by four factors (1)petroleum production, oil spills and illegal bunkering/pipe line vandalization (2) iron/steel industries (3)vehicular emission(4) indiscriminate dumping of waste. The $\mathrm{R}$ and $\mathrm{Q}$ mode cluster analysis yielded three clusters respectively. The Contamination Factor (CF)showed that the sediments have considerable level of $\mathrm{Cr}$ contamination at locations $\mathrm{B} 2, \mathrm{~B} 3, \mathrm{~B} 4$ and $\mathrm{B} 6$ while $\mathrm{Fe}, \mathrm{Zn}, \mathrm{Ni}, \mathrm{V}, \mathrm{Pb}, \mathrm{Cd}$, $\mathrm{Mn}$ and $\mathrm{Cu}$ exhibited moderate contamination at locations B1-B7.The Pollution Load Index (PLI)revealed that locations B1-B6 shown progressive site deterioration with respect to the nine measured heavy metals. The Enrichment Factor (EF) indicated that $\mathrm{Cr}$ was moderately enriched at locations $\mathrm{B} 1, \mathrm{~B} 2, \mathrm{~B} 4$ and $\mathrm{B} 6$ while $\mathrm{Zn}, \mathrm{Ni}, \mathrm{Cu}, \mathrm{Cd}, \mathrm{Mn}, \mathrm{Fe}, \mathrm{V}$, and $\mathrm{Pb}$ in the sediments ranged from background concentration to minimal enrichment.

Since these heavy metals can become a threat to vegetation and animals and ultimately to humans through the food chain, it is important to continuously monitor the level of pollutants in the environment.

\section{Introduction}

In the last century a growing and rapidly industrializing world has produced greater quantities of common pollutants such as household garbage, sewage and more toxic and persistent contaminants like pesticides, polychlorinated biphenyls (PCBs), dioxin, chlorofluorocarbons (CFCs), heavy metals, radioactive waste, releases from manufacturing and petroleum exploration and production installations and others. 
P. N. Jire, E.G. Imeokparia; Statistical Evaluation of The Heavy Metals in the Sediments of Warri River and Environs. Advances in I mage and Video Processing, Volume 6 No 3, June (2016); pp: 1-16

According to Ndiokwere (2004) pollutants affect the ecosystems in a variety of ways. Pesticides and heavy metals may harm exposed organisms by being acutely toxic or by accumulating in plant and animal tissues through repeated exposures.

Trace amounts of heavy metals are always present in fresh waters from terrigenous sources such as weathering of rocks resulting into geochemical recycling of heavy metal elements in these ecosystems (Blaser et al; 2000, Sekabira et al, 2010).

Volcanoes have been reported to emit high levels of $\mathrm{Al}, \mathrm{Zn}, \mathrm{Mn}, \mathrm{Pb}, \mathrm{Ni}, \mathrm{Cu}$ and $\mathrm{Hg}$ along with toxic and harmful gases (Seaward and Richardson 1990). Wind dust which arises from desert region such as Sahara, has high levels of Fe and lesser amounts of $\mathrm{Mn}, \mathrm{Zn}, \mathrm{Cr}$, Ni and $\mathrm{Pb}$ (Ross, 1994). The contribution to ecosystem of elements from sea sprays and mist, often transported many kilometres in land is widely recognized. $\mathrm{Cu}$ and $\mathrm{Mn}$ from such marine sources have been detected in rain water input to terrestrial environments.(Vermette and Bingham, 1986. In addition heavy metals may enter into aquatic ecosystems from anthropogenic sources such as industrial waste water discharges sewage wastewater, fossil fuel combustion and atmospheric deposition (Ross 1994, Linnik and Zubenko, 2000, Lwanga et al 2003, Idress, 2009).

Contamination of surface and subsurface environment by heavy metals has established the need to understand metal soil/sediment interactions. Trace elements may be immobilized within the stream sediments and thus could be involved in absorption, co-precipitation and complex formation (Salomons and Forstnes, 1980, Mohiuddin et al 2010).

Warri is a medium sized metropolitan city in the Niger Delta area of Southern Nigeria. It is characterized by extensive petroleum exploration, production and petrochemical activities. It's urbanization has also been dominated by timber and sawmill industries, discharge of untreated sewage into the river systems and generation of municipal wastes containing among others spent motor oils from numerous roadside mechanic workshops (Imeokparia et al., 2009).

This study aims at assessing the geochemistry of the stream sediments of warri river and its tributaries so as to establish the possibility of secondary pollution and determine the source apportionment of heavy metals, using statistical and environmental parameters.

\section{The Study Area}

Warri is among the fastest growing cities in Southern Nigeria. The city is located within the tropical rainforest belt dominated by abundant rainfall (Egborge 2001). The annual ten-year mean is about $2652 \mathrm{~mm}$ while the mean daily temperature is 31.20C (Nigerian Meteorological Agency, 2003).

The Warri River is among the four major coastal rivers of Delta State, Nigeria, and ranks as one of the most commercially utilized rivers in the Niger Delta of Nigeria. It stretches within Latitudes $5^{0} 21^{\prime}-6^{0} 00^{\prime} N$ and Longitude $5^{0} 24^{\prime}-6^{0} 21^{\prime} E$ and covers a surface area of $255 \mathrm{sq} . \mathrm{km}$ with length of about 150km (NEDECO, 1954). It flows from its source around UtagbaUno in a South-west direction through Oviorie and Ovu inland; and southwards at Odiete through Agbarho to Otokutu. Thereafter it turns south west to Effurun and Warri. Important land marks in this river stretches are Enerhen, Igbudu, Ovwian and the industrial towns of Aladja and Warri. (NEDECO, 1954). Three important creeks empty their waters into the main channel of the river. The first is the Miller Creek which drains the densely populated area of Okere in Warri while the other creeks are Tori and Crawford.

The Warri River is joined by series of tributaries on which are located some Itsekiri villages such as Ode-Itsekiri, Orugbo and an ljaw village - Ogbeljaw in the south-east direction (Egborge, 1991). The 
river drains these tributaries and empties into the brackish Forcados River which in turn empties into the Atlantic Ocean (Benka-Coker, 1983). According to NEDECO (1954), the Warri River and its tributaries are influenced by oceanic tidal variations from Warri to Forcados (Nigerian Navy, 1982).

\section{Geology}

The study area is underlain by the deposits of the Quaternary Sombreiro-Warri Deltaic Plain Sands that conformably overlie the Benin Formation (Wigwe, 1975) (Fig.1).This Formation consists of fine to medium and coarse-grained unconsolidated sands that are often feldspathic, with $30-40 \mathrm{wt} \%$ feldspars and occasionally gravelly. This sequence is locally stratified with peat and lenses of soft and plastic clay that could be sandy. The Formation generally does not exceed 120 metres in thickness and it is predominantly unconfined.

Unfortunately, this near surface and shallow Quaternary cover appears not to have received as much attention. The practice has been to generally lump these deposits of alternating fine-medium-grained sands, silts and subordinate lensoid clays together as the recent and present day deposition of sediments on the Benin Formation (Amajor, 1991). However, these important deposits possess distinct characteristics and engineering properties (Bam, 2007), and cover more than 70 per cent of the land surface of Delta State, Nigeria. They are exploited for glass sands and quarried extensively for building purposes (Bam, 2007; Akpokodje and Etu-Efeotor, 1987; Ministry of Commerce and Industry, 2001; Atakpo and Akpoborie, 2011). Furthermore, they constitute the shallow aquifers that are exploited by shallow $(<30 \mathrm{~m})$ boreholes and dug wells that serve as the primary water supply source for rural as well as many sub-urban and urban communities.

The quality of water yielded is also very crucial but various studies (Ejechi et al., 2007; Akpoborie et al. 2000; Olobaniyi et al. 2007; Abimbola et al. 2002) have indicated that these shallow aquifers are highly vulnerable to contamination from surface sources resulting in quality being compromised.

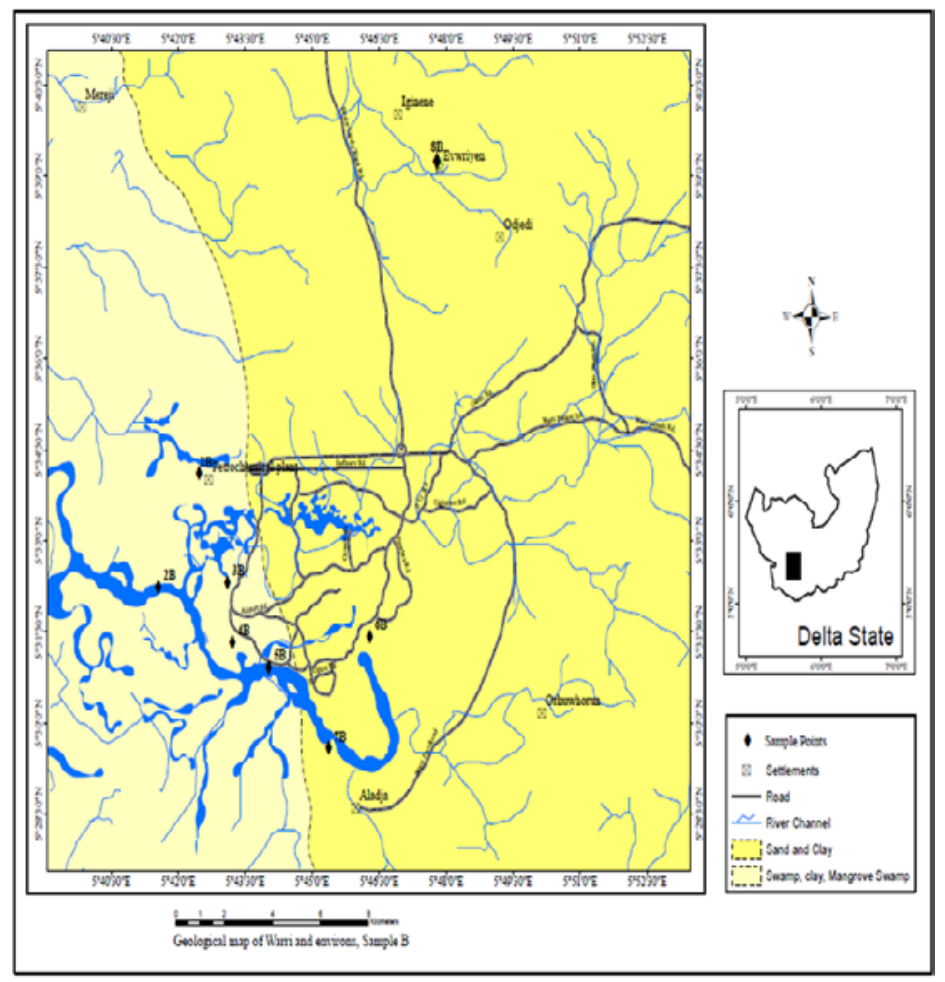

Figure. 1: Geology of Warri and Environs, showing also sample location 


\section{Materials and Methods}

Stream sediments were collected along the Warri River, its three principal creeks and control points at Evwriyen during the raining and dry season (Figs. 2 and 3). GPS was used for the location of sample points.

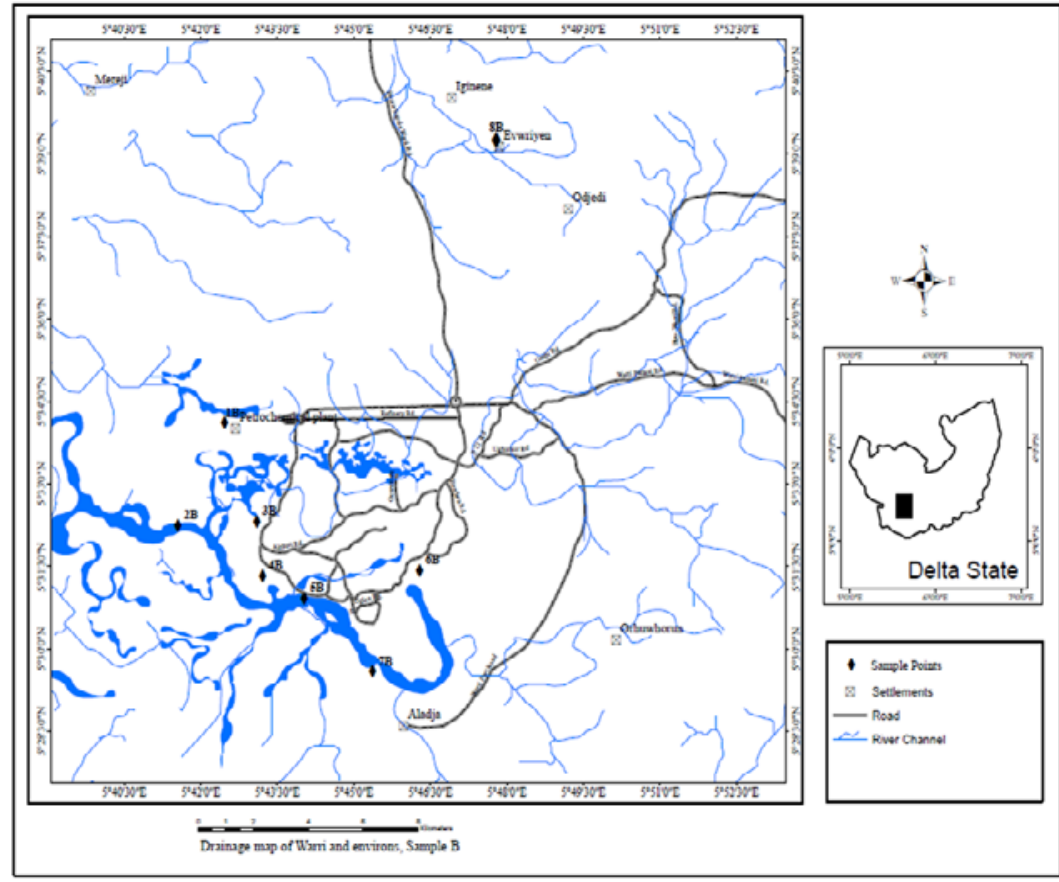

Fig.2. Drainage Map of Warri and Environs and Sample Locations

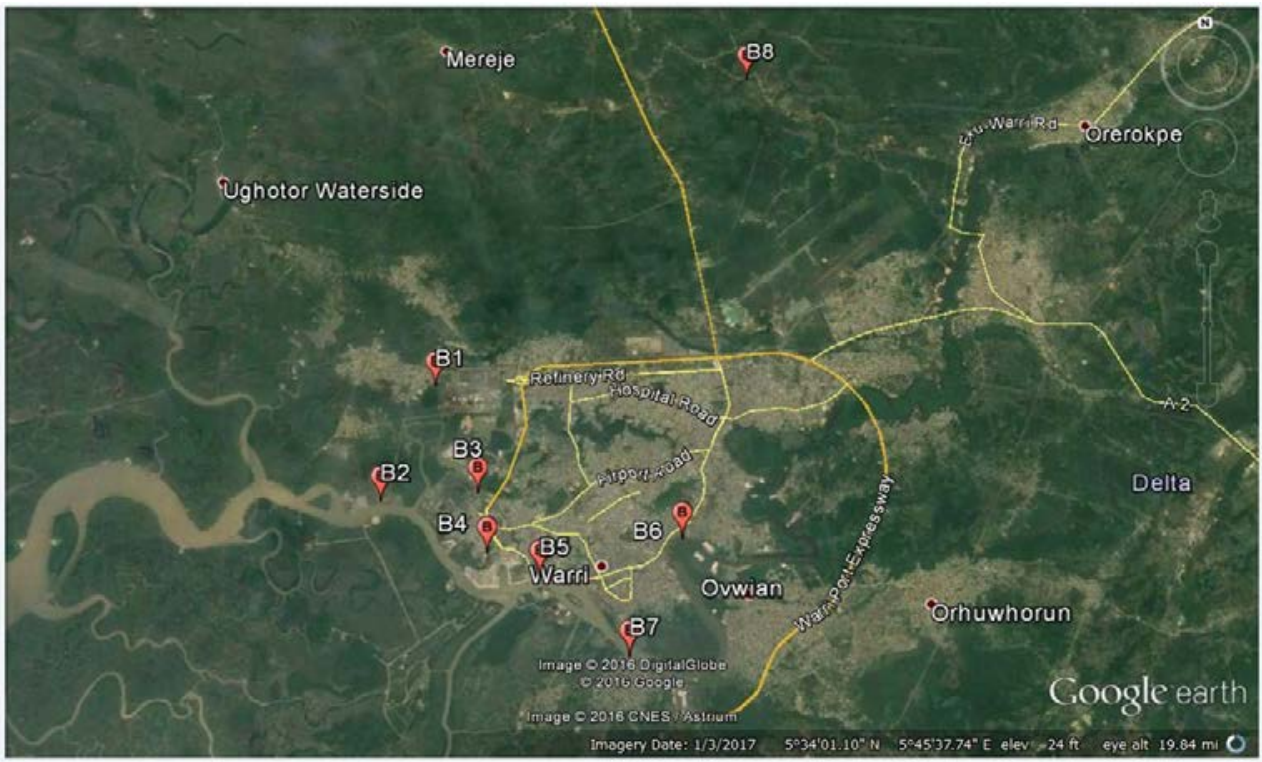

Fig. 3. Aerial Photograph of Warri and Environs showing Sample Locations

\section{Sediment Sampling and Chemical Analysis}

The stream sediments were collected during the raining and dry season along the Warri river and its tributaries (Fig. 2) and Evwriyen stream (the control) using a hand trowel. The samples were immediately placed into well labeled bags made from soft cloth material.

The samples were pretreated of debris and dried at $105^{\circ} \mathrm{C}$ in a moisture extraction oven overnight. The dried samples were sieved mechanically using a $0.5 \mathrm{~mm}$ sieve homogenized and ground to $0.063 \mathrm{~mm}$ fine powder. 
1.0g of each sample was digested using $5 \mathrm{ml}(3: 2)$ nitric $\left(\mathrm{HNO}_{3}\right)$ and perchloric $\left(\mathrm{HClO}_{4}\right)$ acid on sand bath evaporated to near dryness. The digested samples were then leached with $5 \mathrm{ml}$ of dilute $\mathrm{HCl}$. The residue was washed several times into $100 \mathrm{ml}$ volumetric flask and made up to mark. The trace metals in the digest were determined by atomic absorption spectroscopy (Ramirez - Munoz 1968). Accuracy of the analytical method was evaluated my comparing the expected metal concentrations in certified reference materials with the measured values. Simultaneous performance of analytical blanks, standard reference and duplicate samples showed that the accuracy of method was within acceptable limits.

\section{Data Analysis}

All mathematical and statistical computations were carried out using Microsoft (office) Excel 20B software and SPSS (ver 22).

The multivariate statistical analyses were applied to the data, standardized through Z-scale transformation to avoid misclassification due to wide differences in data dimensionality (Yang et al., 2009). The correlation matrix which was based on calculating the Pearson's correlation coefficient was utilized for displaying relationships between variables. In this way the relationships were easier to interpret since only values between +1 and -1 were taken (Navarro et al, 2008).

Mathematically, principal component analysis (PCA) and Factor Analysis (FA) involve the following five (5) major steps.

(i) Start by coding the variables to have zero means and unit variance.(ii) Calculate the covariance matrix, (iii) find eigenvalues and corresponding eigenvectors, (iv) discard any component that only account for small proportion of variation in data set, $(v)$ develop the factor loading matrix and perform varimax rotation on the factor loading matrix to infer the principal parameters (Lokhande, et al., 2008). In this study, only components or factors exhibiting an eigenvalues of greater than one were retained (Reghunath et al., 2002).

\section{Hierarchical Cluster Analysis}

Cluster analysis was performed to further classify elements of different sources on the basis of similar chemical properties. In order to discriminate the distinct groups of heavy metals of natural or anthropogenic sources, the result obtained from a hierarchical cluster enabled the identification of elements (Harikumar et al., 2010). Hierarchical cluster analysis was used to find the true groups of data. Cluster analysis was performed on the normalized data sets by means of the Ward's method, using squared Euclidean distances as a measure of similarity (Laluraj, et al, 2005). The spatial variability in the data sets was determined by cluster analysis, using the linkage distance which represented the quotient between the linkage distances for a particular case divided by the maximal linkage distance. The quotient was then multiplied by 100 to standardize the linkage distance represented on the $y$ axis.

In clustering, the objects were grouped such that similar objects fell into the same class. Hierarchical clustering joined the most similar observations and successively the next most similar observations (Lokhande et al., 2008). The level of similarity at which observations were merged were used to construct dendrogram. In this study, squared Euclidean distance and Ward's were used to construct dendrogram. A short distance shows that the two objects were similar or close together whereas a long distance indicated dissimilarity (Lokhande et al., 2008). Hierarchical cluster analysis using dendrograms identified relatively homogeneous groups of variables with similar properties and combined clusters until only one was left. (Praveena et al., 2007). Each clustered group showed a 
P. N. Jire, E.G. Imeokparia; Statistical Evaluation of The Heavy Metals in the Sediments of Warri River and Environs. Advances in I mage and Video Processing, Volume 6 No 3, J une (2016); pp: 1-16

specific and similar ecological state of the ecosystem. For clustering analysis, the data were standardized to equalize the influence of parameters.

\section{Factor Analysis}

The purpose of factor analysis (FA) is the description of the observed variables in complex environmental compartments by finding summarizing factors, which are often causally explainable (Shakeri et al 2009). The extracted factors reflect the main part of information of the data set. The mathematical principles of actor analysis has been described by Reghunath et al (2002).

For factor analysis varimax and Kaiser normalization rotation method was used (Kaiser, 1958) and also used to find association between parameters so that the number of measured variable can be reduced.

\section{Assessment of Sediment Contamination}

To evaluate the magnitude of contamination (natural and anthropogenic) in the environment, the enrichment factor (EF) as proposed by Simex and Helz (1981) was computed relative to the abundance of species in source materials to that found in an unpolluted area with similar geology.

The following equation was used to calculate the EF values:

$$
E F=\left(C_{m} / \mathrm{CFe}\right) \text { sample } /\left(C_{m} / C F e\right) \text { control/background value, where }\left(C_{m} / C_{r}\right) .
$$

Sample is the ratio of concentration of heavy metal $\left(\mathrm{C}_{\mathrm{m}}\right)$ to that of $\mathrm{Fe}\left(\mathrm{CF}_{\mathrm{e}}\right)$ in the stream sediment and $\left(C_{m} / \mathrm{CFe}\right)$

control / background value is the reference ratio in the control/background.

Fe was chosen as the element of normalization because natural sources $1.5 \%$ vastly dominate its input. It is the most commonly used normalization factor (Loska et al 2003; Seshan et al., 2010). Fe, particularly the redox sensitive iron-hydroxide and oxide under oxidation condition constitutes significant sink of heavy metals in aquatic system. Even a low percentage of $\mathrm{Fe}(\mathrm{OH})_{3}$, in aquatic system, has a controlling influence on heavy metal distribution. Therefore, $\mathrm{Fe}$ is taken as a normalization element while determining enrichment factor (Chakravarty and Patgiri, 2009, Harikumar et al, 2010; Fagbote and Olanipekun, 2010).

Five (5) contamination categories were recognized on the basis of the enrichment factors as follows (Sutherland, 2000)

$\mathrm{EF}<2$ is deficiency to minimal enrichment

EF $2-5$ is moderate enrichment

EF $5-20$ is significant enrichment

EF $20-40$ is very high enrichment

$E F>40$ is extremely high enrichment

As the $\mathrm{EF}$ values increase, contributions due to anthropogenic origin also increase.

\section{Determination of Contamination Factor (CF)}

The level of contamination of soil/sediment by a metal is often expressed in terms of a contamination factor calculated as follows: 
Contamination factor $=$ metal content in soil, sediment/background value of the metal.

Where $\mathrm{CF}<1$ refers to low contamination

Where $1 \geq C F \geq 3 \quad$ means moderate contamination.

Where $3 \geq C F \geq 6$ indicates considerable contamination

Where $C F \geq 6$ indicates very high contamination (Harikumar and Jisha, 2010). The control point values obtained from unpolluted area with similar geology were used for all the indices.

\section{Pollution Load Index (PLI)}

The extent of pollution by heavy metals has been assessed by employing the method of pollution load index (PLI) developed by Tomilson et al., (1980) and the relationship is shown below.

$$
P L I=\left(C F * C F_{2} * \ldots \ldots *{ }^{*} C F_{n}\right)^{1 / n}
$$

Where $\mathrm{CF}=$ contamination factor and $\mathrm{n}=$ number of metals, (nine in the present study).

PLI provides a simple, comparative means for assessing a site's quality which is interpreted as follows:

A value of zero indicates perfection, while a value of one(1) indicates only baseline levels of pollutants present and values above one (1) indicate progressive deterioration of the site's quality (Tomilson et al., 1980; Harikumar and Jisha, 2010 and Al-Qud et al. 2011).

\section{Results and Discussion}

Table 1: Sediments Heavy Metal Per Location

\begin{tabular}{|c|c|c|c|c|c|c|c|c|c|c|c|c|}
\hline Loc & $\mathbf{p H}$ & $\begin{array}{c}\mathbf{Z n} \\
\mathbf{m g} / \mathbf{k g}\end{array}$ & $\begin{array}{c}\mathbf{C u} \\
\mathbf{m g} / \mathbf{k g}\end{array}$ & $\begin{array}{c}\mathbf{C d} \\
\mathbf{m g} / \mathbf{k g}\end{array}$ & $\begin{array}{c}\mathbf{F e} \\
\mathbf{m g} / \mathbf{k g}\end{array}$ & $\begin{array}{c}\mathbf{P b} \\
\mathbf{m g} / \mathbf{k g}\end{array}$ & $\begin{array}{c}\mathbf{N i} \\
\mathbf{m g} / \mathbf{k g}\end{array}$ & $\begin{array}{c}\mathbf{M n} \\
\mathbf{m g} / \mathbf{k g}\end{array}$ & $\begin{array}{c}\mathbf{C r} \\
\mathbf{m g} / \mathbf{k g}\end{array}$ & $\begin{array}{c}\mathbf{V} / \mathbf{m g} / \mathbf{k g} \\
\mathbf{m g} / \mathbf{k g}\end{array}$ & $\begin{array}{c}\mathbf{T H C} \\
\mathbf{m g} / \mathbf{k g}\end{array}$ \\
\hline B1 & 5.4 & 68.65 & 11.015 & 9.525 & 923.45 & 1.535 & 6.51 & 8.93 & 3.168 & 0.358 & 53.52 & 55.87 \\
\hline B2 & 5.925 & 29.84 & 8.855 & 7.12 & 329.92 & 0.965 & 7.1 & 8.95 & 0.973 & 0.565 & 12.90 & 6.758 \\
\hline B3 & 5.65 & 73.64 & 9.575 & 9.55 & 648.68 & 1.423 & 3.695 & 8.65 & 1.813 & 0.578 & 88.94 & 61.36 \\
\hline B4 & 5.125 & 25.66 & 14.43 & 8.55 & 608.69 & 1.665 & 5.145 & 12.2 & 1.715 & 0.508 & 68.46 & 47.35 \\
\hline B5 & 5.925 & 44.53 & 19.435 & 4.14 & 374.59 & 7.05 & 4.745 & 9.1 & 0.44 & 0.378 & 82.28 & 70.07 \\
\hline B6 & 5.425 & 17.74 & 13.925 & 15.915 & 442.90 & 2.758 & 4.87 & 12 & 1.12 & 0.793 & 92.52 & 77.98 \\
\hline B7 & 6.075 & 27.56 & 19.17 & 6.37 & 382.04 & 4.895 & 1.665 & 10.5 & 0.538 & 0.503 & 8.435 & 4.77 \\
\hline B8 & 5.725 & 29.18 & 15.295 & 4.285 & 318.52 & 1.225 & 3.095 & 12.1 & 0.38 & 0.42 & 14.67 & 4.28 \\
\hline AV & 5.656 & 39.60 & 13.96 & 8.182 & 503.60 & 2.69 & 4.60 & 10.3 & 1.27 & 0.51 & 52.71 & 41.05 \\
\hline
\end{tabular}

Table 2: Correlation Matrix of Location B1- B8 Sediments Heavy Metals

\begin{tabular}{|ll|r|r|r|r|r|r|r|}
\hline & & \multicolumn{1}{c|}{$\mathrm{pH}$} & \multicolumn{1}{c|}{ OrgC } & \multicolumn{1}{c|}{$\mathrm{Zn}$} & \multicolumn{1}{c|}{$\mathrm{Cu}$} & \multicolumn{1}{c|}{$\mathrm{Cd}$} & \multicolumn{1}{c|}{$\mathrm{Fe}$} & \multicolumn{1}{c|}{$\mathrm{Pb}$} \\
\hline Correlation & $\mathrm{pH}$ & 1.000 & .047 & -.477 & -.465 & -.767 & -.762 & -.528 \\
& $\mathrm{OrgC}$ & .047 & 1.000 & .252 & .193 & -.067 & .089 & .225 \\
& $\mathrm{Zn}$ & -.477 & .252 & 1.000 & .736 & .412 & .643 & .386 \\
& $\mathrm{Cu}$ & -.465 & .193 & .736 & 1.000 & .475 & .582 & .567 \\
$\mathrm{Cd}$ & -.767 & -.067 & .412 & .475 & 1.000 & .846 & .517 \\
$\mathrm{Fe}$ & -.762 & .089 & .643 & .582 & .846 & 1.000 & .591 \\
$\mathrm{~Pb}$ & -.528 & .225 & .386 & .567 & .517 & .591 & 1.000 \\
$\mathrm{Ni}$ & -.387 & .337 & .666 & .601 & .326 & .384 & .372 \\
$\mathrm{Mn}$ & -.414 & -.370 & -.083 & -.066 & .580 & .501 & .058 \\
$\mathrm{Cr}$ & -.496 & .229 & .494 & .303 & .325 & .490 & .176 \\
$\mathrm{~V}$ & .083 & -.197 & -.157 & -.104 & -.024 & -.190 & -.329 \\
$\mathrm{THC}$ & -.206 & .393 & -.033 & -.016 & .195 & .204 & .260 \\
\hline
\end{tabular}




\begin{tabular}{|ll|r|r|r|r|r|}
\hline & & \multicolumn{1}{|c|}{$\mathrm{Ni}$} & $\mathrm{Mn}$ & \multicolumn{1}{c|}{$\mathrm{Cr}$} & \multicolumn{1}{c|}{$\mathrm{V}$} & \multicolumn{1}{c|}{$\mathrm{THC}$} \\
\hline Correlation & $\mathrm{pH}$ & -.387 & -.414 & -.496 & .083 & -.206 \\
& $\mathrm{OrgC}$ & .337 & -.370 & .229 & -.197 & .393 \\
& $\mathrm{Zn}$ & .666 & -.083 & .494 & -.157 & -.033 \\
& $\mathrm{Cu}$ & .601 & -.066 & .303 & -.104 & -.016 \\
& $\mathrm{Cd}$ & .326 & .580 & .325 & -.024 & .195 \\
& $\mathrm{Fe}$ & .384 & .501 & .490 & -.190 & .204 \\
& $\mathrm{~Pb}$ & .372 & .058 & .176 & -.329 & .260 \\
$\mathrm{Ni}$ & 1.000 & -.229 & .410 & .102 & .226 \\
& $\mathrm{Mn}$ & -.229 & 1.000 & .025 & .071 & .148 \\
$\mathrm{Cr}$ & .410 & .025 & 1.000 & .118 & .218 \\
$\mathrm{~V}$ & .102 & .071 & .118 & 1.000 & .216 \\
& $\mathrm{THC}$ & .226 & .148 & .218 & .216 & 1.000 \\
\hline
\end{tabular}

The correlation matrix in Table 2 revealed significant correlation ( $r=>0.70)$ between $\mathrm{Zn}-\mathrm{Cu}, \mathrm{Cd}-\mathrm{Fe}$, $\mathrm{pH}-\mathrm{Cd}$ (neg) and pH-Fe(neg.) which suggests a common origin(Yisa et al., 2011). Some of the sediments heavy metals exhibited poor to mild correlation with all measured parameters and this denote diverse source or origin (Ata et al.2009).

Table 3.Varimax Rotated Factor Analysis of Sediments Heavy Metals

\begin{tabular}{|l|r|r|r|r|r|r|}
\hline \multirow{2}{*}{ Component } & \multicolumn{3}{|c|}{ Initial Eigenvalues } & \multicolumn{3}{c|}{ Rotation Sums of Squared Loadings } \\
\cline { 2 - 7 } & \multicolumn{1}{|c|}{ Total } & \% of Variance & Cumulative \% & \multicolumn{1}{c|}{ Total } & \% of Variance & Cumulative \% \\
\hline 1 & 4.777 & 39.810 & 39.810 & 3.357 & 27.975 & 27.975 \\
2 & 2.083 & 17.360 & 57.170 & 3.100 & 25.831 & 53.806 \\
3 & 1.442 & 12.015 & 69.185 & 1.563 & 13.029 & 66.835 \\
4 & 1.213 & 10.110 & 79.295 & 1.495 & 12.460 & 79.295 \\
5 & .764 & 6.368 & 85.662 & & & \\
6 & .485 & 4.044 & 89.706 & & & \\
7 & .353 & 2.945 & 92.651 & & & \\
8 & .282 & 2.347 & 94.999 & & & \\
9 & .212 & 1.769 & 96.767 & & & \\
10 & .172 & 1.434 & 98.201 & & & \\
11 & .156 & 1.296 & 99.497 & & & \\
12 & .060 & .503 & 100.000 & & & \\
\hline
\end{tabular}

The Factor analysis performed on the sediments heavy metal extracted four factors which accounted for $79.3 \%$ of the total variance(Tables 3 and 4).Factor one consists of high factor loading on $\mathrm{Zn}, \mathrm{Ni}, \mathrm{Cu}$ and $\mathrm{Cr}$ and reflects anthropogenic input from petroleum related activities (Riccardi et al., 2008). Factor two is dominated by $\mathrm{Cd}, \mathrm{Mn}$ and Fe with negative loading on $\mathrm{pH}$ and suggests anthropogenic input from indiscriminate dumping of metal scraps in streams and effluents from iron/steel foundry industries around the area. Factor three has high loading on $\mathrm{THC}$ and $\mathrm{OrgC}$ and reflects anthropogenic input from the various hydrocarbon spill in the area. Factor four is dominated by $V$ with negative loading on $\mathrm{Pb}$ and suggests anthropogenic input from petroleum refinery and vehicular emission in the study area. 
Table 4: Factor Loading of Sediments Heavy Metals

\begin{tabular}{|l|l|l|r|r|}
\hline \multirow{2}{*}{} & \multicolumn{5}{|c|}{ Component } \\
\cline { 2 - 5 } & 1 & 2 & 3 & \multicolumn{1}{l|}{4} \\
\hline $\mathrm{Zn}$ & .884 & .164 & -.050 & -.160 \\
$\mathrm{Cu}$ & .831 & .008 & .246 & .076 \\
$\mathrm{Cr}$ & .803 & .212 & -.051 & -.253 \\
$\mathrm{Cd}$ & .595 & .247 & .242 & .282 \\
$\mathrm{Mn}$ & .336 & .858 & .051 & -.078 \\
$\mathrm{Fe}$ & -.306 & .856 & -.084 & .123 \\
$\mathrm{pH}$ & .497 & .776 & .103 & -.214 \\
$\mathrm{THC}$ & -.444 & -.755 & -.078 & .065 \\
$\mathrm{OrgC}$ & -.043 & .242 & .892 & .179 \\
$\mathrm{~V}$ & .299 & -.315 & .722 & -.288 \\
$\mathrm{~Pb}$ & .029 & -.003 & .073 & .908 \\
& .378 & .409 & .298 & -.556 \\
\hline
\end{tabular}

The Q-mode Cluster analysis performed on the sediment heavy metals extracted three major clusters. Cluster one consists of locations 1, 6 and 4 with one and 6 exhibiting great similarity. Cluster two is made up of locations 2 and 7. Cluster three comprises locations 3, 5 and 8 with 3 and 5 displaying some degree of similarity. Cluster one is related to Clusters two and three at maximum distance of 25, while Clusters two and three are related at euclidian distance of 18 (Fig.4.).

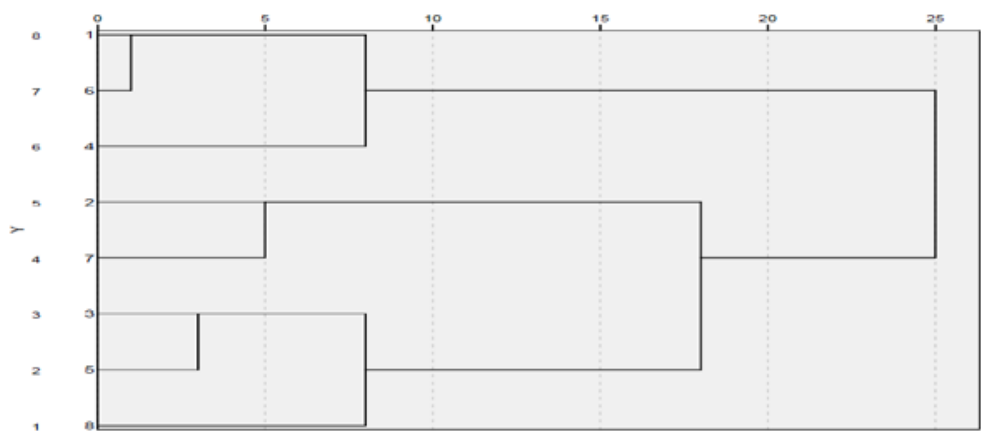

Figure 4. Q-mode Cluster Analysis of Sediments Heavy Metals

The R-mode cluster analysis performed on the sediments heavy metal extracted three clusters (Fig.5). Cluster one consists of $\mathrm{Zn}, \mathrm{Cu}, \mathrm{OrgC}, \mathrm{THC}, \mathrm{Cd}$, and $\mathrm{Mn}$. In this cluster, both $\mathrm{Cu}$ and $\mathrm{Zn}$, as well as $\mathrm{Cd}$ and $\mathrm{Mn}$ exhibit great similarity. This cluster is similar to Factors one, two and three to some extent. Cluster two is made up of $\mathrm{Cr}, \mathrm{V}, \mathrm{Pb}$ and $\mathrm{Ni}$ and exhibits some similarity with factors one and four. Cluster three on the other hand is made up of $\mathrm{pH}$ and Fe and partly similar to factor two.

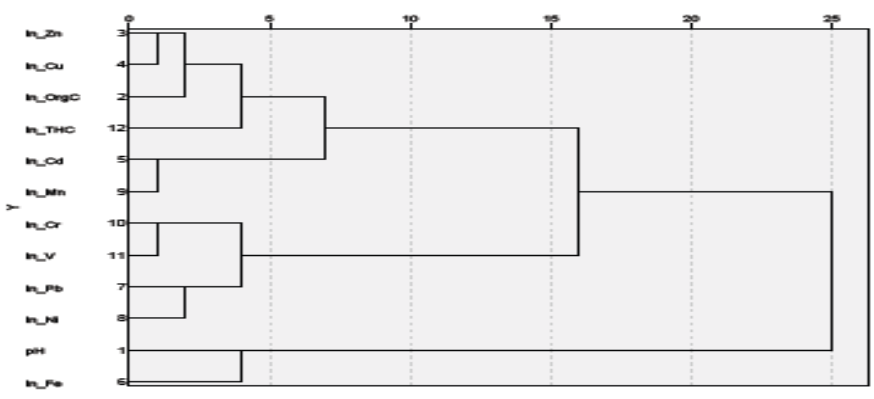

Figure 5: R-mode Cluster Analysis of Sediments Heavy Metals 
P. N. Jire, E.G. Imeokparia; Statistical Evaluation of The Heavy Metals in the Sediments of Warri River and Environs. Advances in I mage and Video Processing, Volume 6 No 3, J une (2016); pp: 1-16

\section{Sediments Contamination Factor}

The average contamination factor values for the sediments heavy metals range from 0.686 for $\mathrm{Cu}$ to 3.718 for $\mathrm{Cr}$ (Table 5).

The ranked order of contamination factor (CF) among the heavy metals was as follows (Table 5): $\mathrm{Cr}$ $>\mathrm{Mn}>\mathrm{Fe}>\mathrm{Pb}>\mathrm{V}>\mathrm{Ni}>\mathrm{Cd}>\mathrm{Zn}>\mathrm{Cu}$

Cr had a maximum sediments average contamination factor value of 3.72 while a minimum average value of 0.69 was obtained for $\mathrm{Cu}$ (Table 5.). Based on Hakanson, 1980 indices, $\mathrm{Cr}$ had very high range of contamination at location B1, with considerable contamination level at locations B2, B3, B4 and B6, while locations B5 and B7 recorded moderate range of Cr contamination. Locations B1-B7 were moderately contaminated by $\mathrm{Mn}, \mathrm{Fe}, \mathrm{Ni}, \mathrm{Pb}, \mathrm{V}, \mathrm{Zn}$ and Cd, while low Cu contamination was obtained at several locations (Fig.6).

\begin{tabular}{|c|c|c|c|c|c|c|c|c|c|c|}
\hline & \multicolumn{9}{|c|}{ Table 5. Sediments Contamination Factor } & \multirow{2}{*}{$\begin{array}{c}\text { Pollution } \\
\text { Load } \\
\text { Index }\end{array}$} \\
\hline & $\mathrm{Zn}$ & $\mathrm{Cu}$ & $\mathrm{Cd}$ & $\mathrm{Fe}$ & $\mathrm{Pb}$ & $\mathrm{Ni}$ & $\mathrm{Mn}$ & $\mathrm{Cr}$ & $\mathrm{V}$ & \\
\hline B1 & 0.939574 & 0.369624 & 1.164486 & 1.886088 & 1.372121 & 1.109459 & 1.635425 & 6.964318 & 0.900806 & 1.3169191 \\
\hline B2 & 0.857983 & 0.487393 & 0.837674 & 1.036285 & 0.741450 & 2.031887 & 1.828588 & 3.534199 & 1.288936 & 1.1835053 \\
\hline B4 & 0.988412 & 0.902535 & 1.345879 & 2.149058 & 2.598611 & 0.954886 & 1.649486 & 4.688781 & 1.239057 & 1.5799739 \\
\hline B5 & 1.294454 & 0.748779 & 0.664832 & 1.492275 & 1.612216 & 0.931473 & 2.839412 & 1.052348 & 1.047496 & 1.1824772 \\
\hline B6 & 0.521427 & 0.967798 & 0.974299 & 1.258983 & 1.354750 & 1.446635 & 1.869381 & 3.776467 & 1.543229 & 1.3321991 \\
\hline B7 & 0.849703 & 0.931623 & 1.257864 & 1.214725 & 1.130584 & 0.128300 & 2.378833 & 1.779327 & 0.824475 & 0.9469507 \\
\hline Average & 1.000033 & 0.685819 & 1.051650 & 1.655839 & 1.422872 & 1.086366 & 2.080245 & 3.717832 & 1.198074 & \\
\hline
\end{tabular}




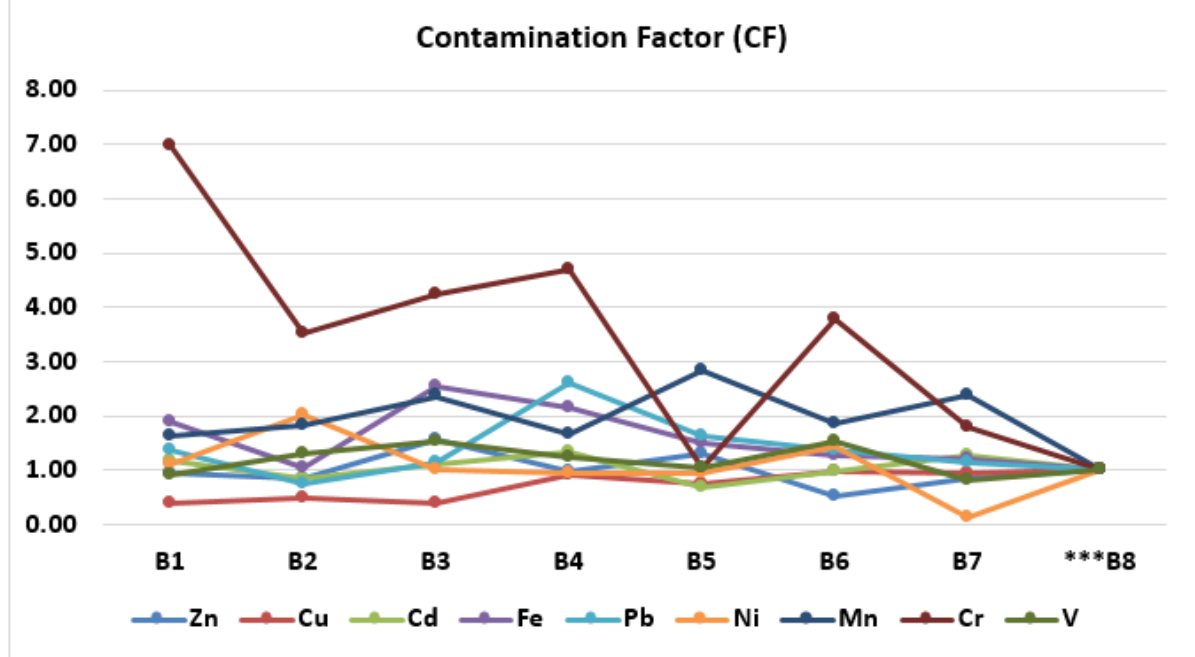

Figure 6: Contamination Factor Graph of Locations B1 - B8 Sediments Sediments Pollution Load Index (PLI)

The pollution load index (PLI) revealed that location B4 had maximum pollution load index of 1.58 and a minimum pollution load index value of 0.95 was obtained at location B7 (Table 5). The order of pollution load index per location for the sediments was as follows:

$$
\mathrm{B} 4>\mathrm{B} 3>\mathrm{B} 6>\mathrm{B} 1>\mathrm{B} 2>\mathrm{B} 5>\mathrm{B} 7 \text {. }
$$

Based on Tomilson et al., 1980 indices, locations B1 to B6 have shown progressive site deterioration with respect to the measured nine (9) heavy metals, while location B7 had only baseline level of pollutants present (Figs.7 and 8).

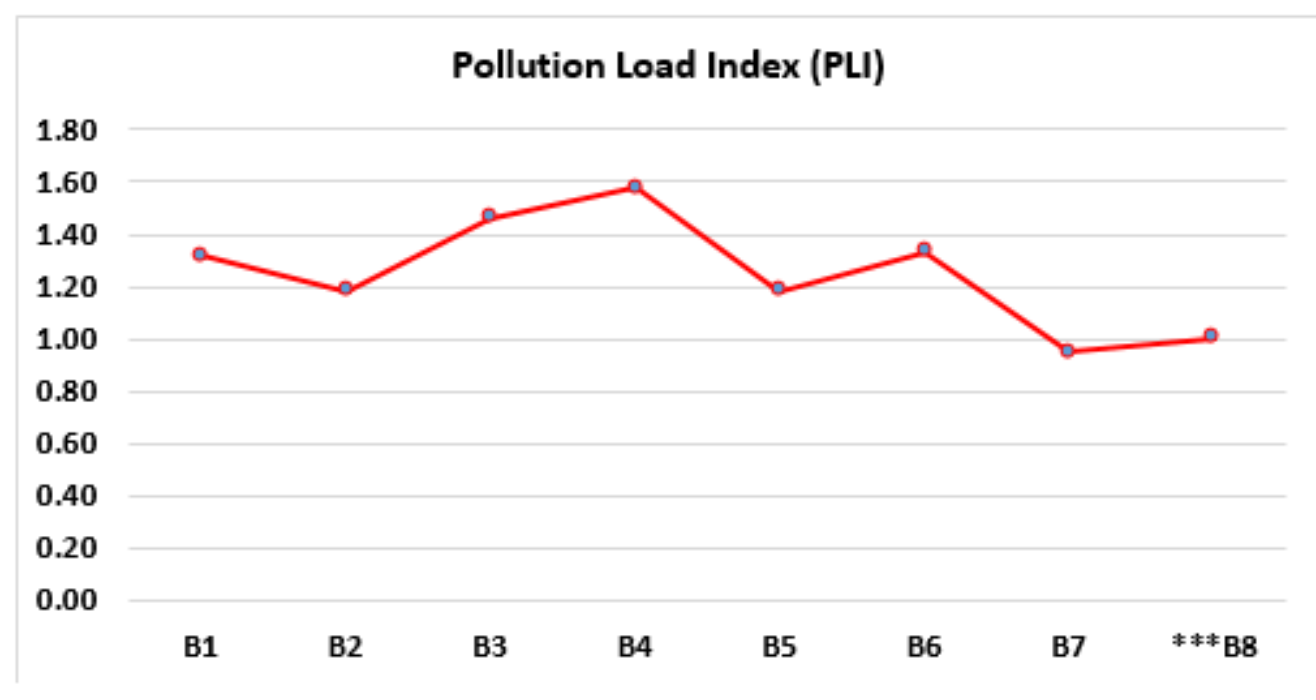

Figure 7: Pollution Load Index (PLI) Graph of Locations B1 - B8 Sediments 


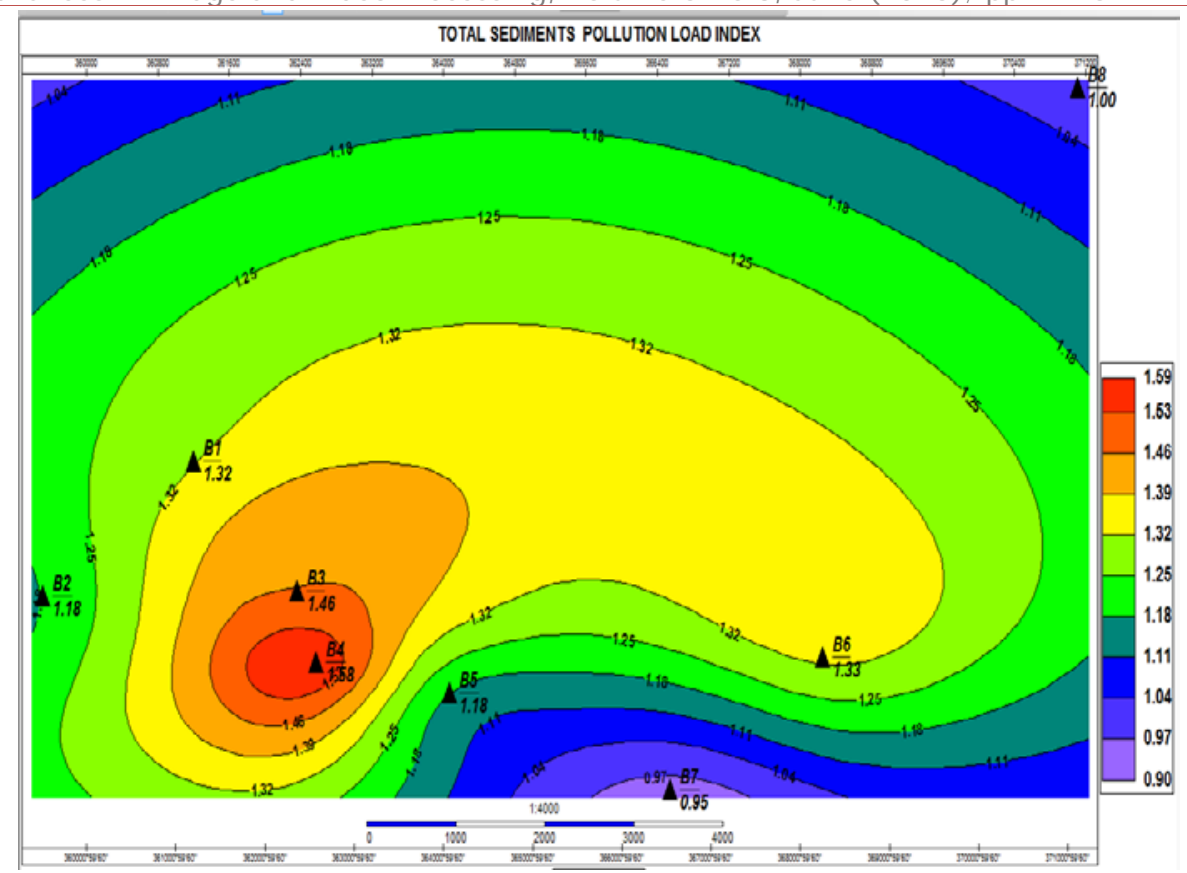

Figure 8: Sediments Pollution Load Index Map of Locations B1-B8.

\section{Sediments Enrichment Factor}

The enrichment order for the heavy metals of locations B1 - B7 sediments sample was as follows:

$\mathrm{Cr}>\mathrm{Mn}>\mathrm{Fe}>\mathrm{Pb}>\mathrm{V}>\mathrm{Ni}>\mathrm{Cd}>\mathrm{Zn}>\mathrm{Cu}$ (Table 6).

An EF values between 0.5 and 2.0 is regarded as within the natural range while ratio greater than 2.0 indicates some enrichment corresponding to anthropogenic input (Ata et al., 2009; Sekabira et al., 2010).

Based on Sutherland's 2000 indices, the enrichment factor showed that $\mathrm{Cr}$ was moderatelyenriched at locations B1, B2, B4 and B6. The other heavy metals( $\mathrm{Fe}, \mathrm{Zn}, \mathrm{Ni}, \mathrm{V}, \mathrm{Pb}, \mathrm{Cd}, \mathrm{Mn}$ and $\mathrm{Cu}$ ) were either depleted to minimal enrichment or had background concentration at several locations (Fig. 9).

\begin{tabular}{|c|c|c|c|c|c|c|c|c|c|}
\cline { 2 - 10 } \multicolumn{1}{c|}{} & \multicolumn{8}{c|}{ Table 6. } & \multicolumn{7}{c|}{ Sediments Enrichment Factor for Locations B1-B8 } \\
\cline { 2 - 11 } \multicolumn{1}{c|}{} & $\mathrm{Zn}$ & $\mathrm{Cu}$ & $\mathrm{Cd}$ & $\mathrm{Fe}$ & $\mathrm{Pb}$ & $\mathrm{Ni}$ & $\mathrm{Mn}$ & $\mathrm{Cr}$ & $\mathrm{V}$ \\
\hline B1 & 0.49816 & 0.195974 & 0.617408 & 1 & 0.727495 & 0.588233 & 0.867099 & 3.692467 & 0.477605 \\
\cline { 2 - 11 } B2 & 0.827941 & 0.470327 & 0.808343 & 1 & 0.715488 & 1.960741 & 1.76456 & 3.410449 & 1.243805 \\
B3 & 0.6065 & 0.153902 & 0.437257 & 1 & 0.450515 & 0.392379 & 0.924467 & 1.656333 & 0.604089 \\
B4 & 0.459928 & 0.419968 & 0.626265 & 1 & 1.209186 & 0.444328 & 0.767539 & 2.181784 & 0.576558 \\
B5 & 0.867437 & 0.50177 & 0.445516 & 1 & 1.080374 & 0.624196 & 1.90274 & 0.705197 & 0.701946 \\
B6 & 0.414165 & 0.768714 & 0.773878 & 1 & 1.076067 & 1.149051 & 1.484834 & 2.999617 & 1.225775 \\
\cline { 2 - 10 } B7 & 0.699502 & 0.766942 & 1.035513 & 1 & 0.930733 & 0.105621 & 1.958332 & 1.464799 & 0.678734 \\
B8 & 1 & 1 & 1 & 1 & 1 & 1 & 1 & 1 & 1 \\
\hline Average & 0.624805 & 0.468228 & 0.67774 & & 0.884265 & 0.752078 & 1.381367 & 2.301521 & 0.78693 \\
\hline
\end{tabular}




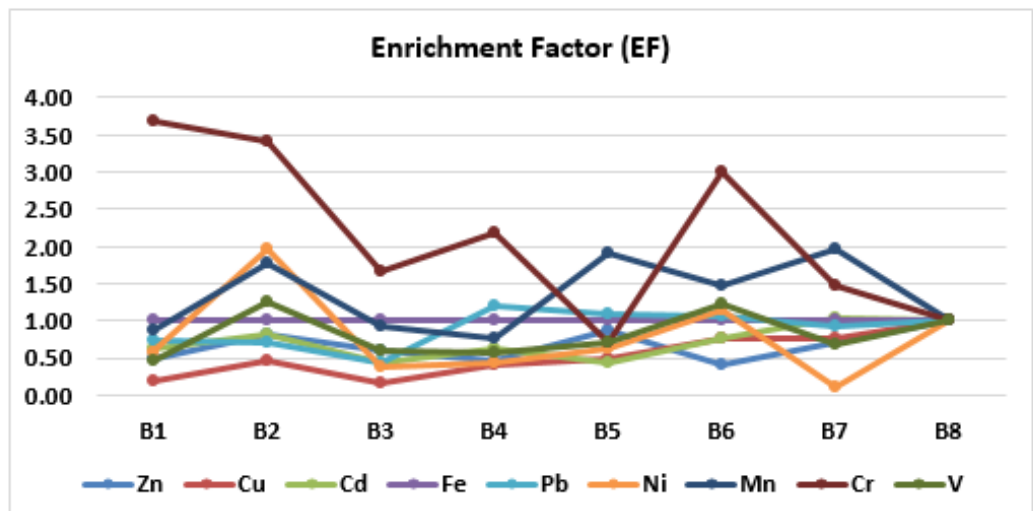

Figure 9: Enrichment Factor(EF) Graph of Locations B1 - B8 Sediments

\section{Conclusion}

Majority of the heavy metals in the sediments exhibited moderate contamination range at several locations, while $\mathrm{Cr}$ has considerably contaminated locations B2, B3, B4 and B6 with high contamination level at location B1.

The computed Pollution Load Index for the sediments heavy metals revealed that locations B1 to B6 have shown progressive site deterioration with respect to the nine (9) measured heavy metals in the area.

The Enrichment Factor for the sediments indicated moderate enrichment for $\mathrm{Cr}$ at locations B1, B2, $\mathrm{B} 4$ and $\mathrm{B} 6$ while $\mathrm{Fe}, \mathrm{Zn}, \mathrm{Ni}, \mathrm{V}, \mathrm{Pb}, \mathrm{Cd}, \mathrm{Mn}$ and $\mathrm{Cu}$ showed background concentration or were depleted to minimal enrichment at several locations.

\section{REFERENCES}

[1] Abimbola, A. F., Oke,S. A. and Olatunji,A. S.,2002. Environmental Impact assessment of waste dump sites on geochemical quality of water and soils in Warri metropolis, southern Nigeria. Water Resources, vol.13, pp.7-11.

[2] Akpoborie, I. A., Ekakite, O. A. and Adaikpoh, E. O., 2000 .The Quality of Groundwater from Dug Wells in Parts of the Western Niger Delta. Knowledge Review, vol. 2(5), pp. 72-75.

[3] Akpokodje, E.G, Etu-Efeotor, J.O., 1987 .The Occurrence and Economic Potential of Clean Sand Deposits of the Niger Delta. J. Afr. Earth Sci., vol. 6 (1), pp. 61-65.

[4] Al-Oud, S.S., Nadeem, M.E.A., and Al-Stibel, B.H., 2011, Distribution of Heavy Metals in Soils and Plants Around a Cement Factory in Riyhadh City, Central of Saudi Arabia. American - Eurasian J. Agric. \& Environ. Sci., 11 (2): pp. $183-191$.

[5] Amajor, L.C., 1991. Aquifers in the Benin Formation (Miocene Recent), Eastern Niger Delta, Nigeria: Lithostratigraphy, Hydraulics, and Water Quality. Environ Geol Water Sci., vol. 17(2), pp. 85-101 
P. N. Jire, E.G. Imeokparia; Statistical Evaluation of The Heavy Metals in the Sediments of Warri River and Environs. Advances in I mage and Video Processing, Volume 6 No 3, J une (2016); pp: 1-16

[6] Ata Shakeni; Farid Moore and SoroushModabberi, 2009. Heavy metal contamination and distribution in the Shiraz Industrial complex zone soil, south Shiraz, Ivan, World Applied Science Journal 6 (3) : 413-425

[7] Atakpo, E. A. and Akpoboriel.A. 2011. Investigation of sand deposit in parts of Okpe LGA, Delta State, Nigeria. Accepted for Publication: Nig. Jnl. Of Science and Environment.

[8] Bam T. K. S., 2007. N soil exploration and foundations in the recent coastal areas of Nigeria, Bulletin of Engineering Geology and the Environment, vol. 53, 13-9.

[9] Benka-Coker, O.M., 1983. Studies of Bacteriological and Physico-chemical parameters of Warri River. M.Sc Thesis, University of Benin.

[10] Blaser, P., Zimmermann, S. Luster, J. Shotyk, W., 2000. Critical Examination of Trace Element Enrichments and Depletions in Soil: $\mathrm{As}, \mathrm{Cr}, \mathrm{Cu}, \mathrm{Ni}, \mathrm{Pb}$ and $\mathrm{Zn}$ in Swiss Forest Soils. Sc. Total Environ $249: 257-280$.

[11] Chakravarty, M., and Patgiri, A.D., 2009. Metal Pollution Assessment in Sediments of the Dikrong River, N.E. India. J., Hum. Ecol, 27(1); $63-67$.

[12] Egborge, A.B.M., 1991. Industrialization and Heavy Metals Pollution in Warri River $32^{\text {nd }}$ Inaugural Lecture, University of Benin, Benin City 1-26

[13] Egborge, A.B.M., 2001. Water quality index application and industrialization and heavy metal pollution in the warri river, Nigeria.Environ. Pollut.12: $27-40$.

[14] Ejechi, B.O., Olobaniyi, S.B., Ogban, F.E., Ugbe, F.C., 2007. Physical and sanitary quality of hand dug well water from oil producing area of Nigeria, Environmental Monitoring and Assessment 128, 495- 501.

[15] Fagbote E.O. and Olanipekun E.O., 2010. Evaluation of the Status of Heavy Metal Pollution of Sediment of Agbabu Bitumen Deposit area, Nigeria. European Journal of Scientific Research. Vol. 41 , Nos. 3, pp. $373-382$

[16] Fagbote, E.O. and Olanipekun, E.O., 2010. Evaluation of the status of heavy metal pollution of soil and plant (chromolaenaodorata) of Agbadu Bitumen Deport Area, Nigeria. AmericanEurasian J. Sci. Res., 5(4): 241- 248.

[17] Hakanson, I., 1980. Ecological Risk Index for Aquatic Pollution Control, a Sedimentological Approach. Water Res., 14:975-1001.

[18] Harikumar, P.S., and Jisha, T.S., 2010. Distribution Pattern of Trace Metal Pollutants in the Sediments of an Urban Wetland in the Southwest Coast of India. International Journal of Engineering science and Technology, Vol. 2(5), pp. 840-850.

[19] Idress, F.A. (2009). Assessment of trace metal distribution and contamination in surface soils of Amman, Jordan. Jour. Chem. 4(1) p77 - 87.

[20] Imeokparia, E.G.; Onyeobi, T.U.S and Abodunde, F.L., 2009. Heavy metal concentration in soil from a mechanic village in Uvwie Local Government area of Delta State. Nig. Jour, Applied Science Vol. 27 p.144-150. 
[21] Laluraj, C.M., Gopinath, G., Dineshkumar, P.K., 2005: Ground water Chemistry of Shallow acquifers in the Coastal zones of Cochin, India. Applied Ecology and Environmental Research 3(1), pp. 133-139.

[22] Linnik, P.M and Zubenko, I.B. (2000). Role of Bottom Sediments in the Secondary Pollution of Aquatic Environment by heavy metals, Lakes and Reservoirs. Resource Management 5(1) pp 11 -21 .

[23] Lokhande, P.B., Patit, V.V., and Mujawar, H.A., 2008. Multivariate Statistical Analysis of Groundwater in the Vicinity of Mahad Industrial area of Konkan region, India. International Journal of Applied Environmental Sciences.

[24] Loska, K., Wiechula, D. Barska B., Cesule, E., Chojnecka A. (2003). Assessment of arsenic enrichment of cultivated soils in Southern Poland. Pol. J.Enviro. Stud. 12(2) p 187 - 192.

[25] Ministry of Commerce and Industry, (2001). Industrial Mineral Raw Material Resources Survey in Delta State. MC\&I, Asaba. 150p.

[26] Mohiuddin, K.M; Zakir, H.M, Otomo, K., Sharmin S. and Shikazono, N., (2010) Geochemical Distribution of Trace metals pollutants in water and sediments of downstream of an urban river. Int. J. Environ. Sci. Tech. 7(1) p 17-28.

[27] Navarro, M.C., Pere-Sirvent, C., Martinez - Sanchez., Vidal, J., Tovar, P.J. and Bech, J., 2008. Abandoned mine sites as a source of contamination by heavy metals: A Case study in a semi-arid zone. Journal of Geochemical Exploration 96pp 183 - 193.

[28] Ndiokwere, C.L., 1984. An investigation of the heavy metal content of sediments and algae from the River Niger and Nigerian Atlantic Coastal waters. Environ. Pollution 7 (B) 247-254.

[29] NEDECO, 1954. (Netherlands Engineering Consultant), The waters of western Nigeria Delta, The Haque

[30] Nigerian Meteorological Agency, 2003. Warri Meteorological Bulletin. In: National Meteorological Report.

[31] Nigerian Navy, 1982. Tide Table Containing tidal predictions for Lagos, Escravos bar, Forecados bar, Bonny town and Calabar, 36pp

[32] Olabaniyi, S.B., Ogban, F.E. Ejechi, B.O., Ugbe, F.C., 2007a. Quality of Groundwater in Delta State, Nigeria. Journal of Environmental Hydrology. 15.

[33] Praveena, S., M., Ahmed, A., Radojevic, M., Abdullah, M.H. and Aris, A.Z., 2007. Factor -Cluster Analysis and Enrichment Study of Mangrove Sediments - An Example from Mengkabong, Sabah. The Malaysian Journal of Analytical Sciences. Vol. 11, no. 2, pp. $421-430$.

[34] Ramirez-Munoz,J.,1968.Atomic Absorption Spectroscopy and Analysis by Atomic Absorption flame Photometry. Elsvier Publishing Co., NY.

[35] Reghunath R.T.R., Sreedhara M.,Reghavan B.R., 2002. The Utility of Multivariate Statistical Techniques in Hydrogeochemical Studies; example from Karnataka, India. Water Research 36, pp. $2437-2442$. 
P. N. Jire, E.G. I meokparia; Statistical Evaluation of The Heavy Metals in the Sediments of Warri River and Environs. Advances in I mage and Video Processing, Volume 6 No 3, J une (2016); pp: 1-16

[36] Riccardi, C., di Filippo, P.Pomata,D.,Incoronato,F., di Basilio,M. Papini, M.P. and Spicaglia, S., 2008. Characterization and distribution of petroleum hydrocarbons and heavy metals in groundwater from three Italian tank farms. Sci. Total Environ., 393: 50-63.

[37] Ross S.M., 1994. Toxic metals in soil-plant systems. Wiley, Chichester, p 469.

[38] Salomons, W., and Forstner U. (1980). Trace metal analysis of polluted sediments part II evaluation of environmental impact. Environ. Techn. Letters 1, p. 506-517.

[39] Seaward, M.R.D. and Richardson, D.H.S., 1990. Atmospheric sources of metal pollution and effects on vegetation. Pp.75-92,

[40] Sekabira, K., Oryem, H.O, Basambo, T.A.,Mutumba, G., Kakudidi,E.,2010. Assessment of heavy metals pollution in urban streams and its tributaries. International Journal of Environment, Science and Technology 7(3),435-446.

[41] Seshan, B.R; Natesan, U.; Deepth, K., (2010). Geochemical and Statistical approach for evaluation of heavy metal pollution in Core Sediments in Southeast cost of India. Int. J. Environ Sci. Tech. $7(2)$ p. $291-306$.

[42] Simex, S.A, Heiz, G.R, (1981). Regional geochemistry of trace elements in Chesapeatre Bay. Environ. Geology 3. P 315-323.

[43] Sutherland, R.A., 2000: Bed sediment-associated trace metals in an urban stream, Oahu, Hawaii, Environmental Geology 39:611-37.

[44] Tomilson, D.C. Wilson, C.J., Harris, C.R., Jeffrey, D.W., 1980. Problem in Assessment of Heavy Metals in Estuaries and the Formation of Pollution Index. Helgol. Wiss. Meeresunlter, 33(1-4), 566 - 575 (10 pages).

[45] United Nations Environmental Protection/Global Program of Action (UNEP/GPA),2004. Why the Marine Environment needs Protection from Heavy Metals. UNEP/GPA Coordination Office. http://www.oceansatlas.org/unatlas/uneptextph/wastesph/2602gpa.

[46] Vermette S.J. and Binghan V.G., 1986. Trace elements in Frobisher Bay rainwater. Arctic 39 (2): 177-179

[47] Vermette S.J. and Binghan V.G., 1986. Trace elements in Frobisher Bay rainwater. Arctic 39 (2): 177-179.

[48] Wanga, M.S; Kanasiime F., Denny P., Scullion J. (2003). Heavy metals in Lake George Uganda with relation to metal concentration in tissues of common fish specie Hydrobiologia 499(1-3) pp. 8393.

[49] Wigwe, G.A., 1975. The Niger Delta Physical. In Ofomata, G.E.K.,(Eu.), Nigeria in Maps: Eastern States (pp 38 - 40). Benin: Ethiope Publ. House.

[50] Yang, Li; Linyu, Xu, Shun, Li 2009. Water quality analysis of the Songhua River Basin using multivariate techniques. Journal of Water Resources and Protection (JWARP)

[51] Yisa, J., Jacob, J.O. and Onoyima, C.C., 2011.Identification of sources of heavy metals pollution in road deposited sediments using multivariate statistical analysis. J. Emerg. Trends gbEng. Appl. Sci., 2: 658-663. 